\title{
From beyond the Kwango - Tracing the Linguistic Origins of Slaves Leaving Angola, 1811-1848
}

$\mathrm{DOI}$

http://dx.doi.org/10.1590/2236-463320161203

Badi Bukas-Yakabuul

Atlanta First Presbyterian Church, Atlanta - EUA

bbukasyakabuul@gmail.com

Daniel B. Domingues da Silva University of Missouri, Columbia EUA dominguesd@missouri.edu
This article is part of a wider project entitled Política e sociedade nas Américas ibéricas: independência e formação do Estado e da nação no Brasil e no Rio da Prata (1750-1850), and is supported by CAPES and by the MINCYT (Argentina).TranslatedbyVivianBosch, whomwe thank for.

\section{Resumo}

O Rio Quango tem sido visto há muito tempo como o limite do acesso dos traficantes de escravos às principais fontes de cativos no interior de Angola, a maior região de embarque de escravos para as Américas. Contudo, não há estimativas sobre o tamanho e a distribuição dessa enorme migração. Este artigo examina registros de africanos libertados de Cuba e Serra Leoa disponíveis no Portal Origens Africanas para estimar o número de escravos provenientes daquela região em particular durante o século XIX além da sua distribuição etnolingüística. Ele demonstra que cerca de 21 porcento dos escravos transportados de Angola naquele período vieram de além Quango, sendo a maioria oriunda dos povos luba, canioque, e suaíli. O artigo também analisa as causas dessa migração, que ajudou a transformar a diáspora africana para as Américas, especialmente para o Brasil e Cuba.

\section{Abstract}

The Kwango River has long been viewed as the limit of the transatlantic traders' access to the main sources of slaves in the interior of Angola, the principal region of slave embarkation to the Americas. However, no estimates of the size and distribution of this huge migration exist. This article examines records of liberated Africans from Cuba and Sierra Leone available on the African Origins Portal to estimate how many slaves came from that particular region in the nineteenth century as well as their ethnolinguistic distribution. It shows that about 21 percent of the slaves leaving Angola in that period came from beyond the Kwango, with the majority coming from among the Luba, Kanyok, and Swahili speaking peoples. The article also analyzes the causes of this migration, which helped shape the African Diaspora to the Americas, especially to Braziland Cuba.

Palavras-chave

Tráfico transatlântico de escravos; Origens; Angola; Brasil; Cuba.

Keywords

Atlantic slave trade; Origins; Angola; Brazil; Cuba. 
MILLER, Joseph C. Way of death. Merchant capitalism and the Angolan slave trade, 17301830. Madison: University of Wisconsin Press, 1988, pp. 146-147; VANSINA, Jan. It never happened:Kinguri'sexodusanditsconsequences. History in Africa, vol. 25, p. 403, 1998; THORNTON, John K. The chronology and causes of lunda expansion to the west, c.1700-1852. Zambia Journal of History, vol. 1, p. 7, 1981.

2 MILLER, Joseph C. Op. Cit., p. 145. Ibidem, p. 146.

4

VANSINA, Jan. Op. Cit., p. 403.

OPPEN, Achim von. Terms of trade and terms of trust. The history and contexts of pre-colonial marketproductionaroundtheupperZambeziand Kasai. Münster: LIT Verlag, 1994, p. 61. THORNTON, John K. Op. Cit., p. 7.
In the nineteenthcentury, Angola servedas the principal source of slaves to the Americas. These slaves came from a vast region in the interior, covering the territory of many countries in present day Central Africa, including Burundi, Congo, the Democratic Republic of the Congo, Gabon, Namibia, Rwanda, Zambia, and Zimbabwe. Historians of the slave trade, such as Joseph Miller, Jan Vansina, and John Thornton, among others, believethat themajority of these slaves camefrom beyond theKwango River, in Angola (see Figure 1 below). ${ }^{1}$ The Kwango River runs south to north with the head located in the Upper Chicapa region. It is a tributary of the Kasai, which flows into the mighty Congo River.The Kwango, located some 300 kilometers from Luanda, the nearest port of slave embarkation, cuts through a large drainage basin of the Central African savanna, inhabited byadiversity ofpeoplespeaking dozens oflanguages, themost prominent being Chokwe, Ruund, Tshiluba, Kiluba, Kanyok, and Swahili, the latter actually a lingua franca that spread from East Africa centuries ago. Access to the Kwango, however, was often controlled by several African polities, most notably the Kingdom of Kasanje, located on the western bank of the Kwango.TheLundaEmpire, which in thenineteenthcentury theneighboring populations regarded it as a sort of paragon of civilization, dominated the eastern bank. Both polities were very protective of their territories, but the wars the Lunda waged mainly in the eighteenth century and the impression they made on their neighbors have often led historians think that the majority of the slaves leaving Angola in the nineteenth century came from beyond the Kwango.

Joseph Miller, for example, argues that from the sixteenth to the nineteenthcentury, slaves camefrom regions situated increasinglyfarther from the coast, as in a great slaving frontier. According to him, in the first decades after 1700, the Lunda"carried the violent phase of slaving east by raiding the wetter and densely inhabited latitudes north of their capitals."2 Miller believes that this pattern continued in the following century, as "the central Lunda, with the population resources of the forest-savanna mosaics conveniently located nearby and available for plunder, postponed the outbreak of civil disorder until after the middle of the nineteenth century," when the traffic was already dying out. ${ }^{3}$ Jan Vansina claims that Lunda expansion north and the spreading of Lunda influence in eastern Angola was linked to the slave trade. ${ }^{4}$ Achim von Oppen sees the entire region east of the Kwango River as a key player in the transatlantic slave trade, supplying "the last great batch of slaves for export, with peaks around 1820 and in the mid-1830s which were glorified by traders as'the golden years' [of the traffic]." Finally, John Thornton argues that, from the eighteenth century, the Lunda became increasingly attracted to the lands east of the Kwango River, because it brought them closer to their trading partners, the Portuguese, and shortened the routes to the coast. It also provided them with the possibility of capturing more prisoners of war. As Thornton explains, "one might see the Lunda expansion as something of an extended slave raid which ultimately turned much of the land between the Lunda homeland and the Kwango River into a systematically pillaged source of slaves."

However, names of Africans rescued from slave ships, mainly in the 1830 s and 1840s, indicate that slaves coming from beyond the Kwango were a minority in terms of the trade. These names were collected from lists of liberated Africans from Cuba and Sierra Leone made between 1808 and 1862 . Soon after the British abolished their trade in 1807, they 
DOMINGUES DA SILVA Daniel B.; ELTIS, David; MISEVICH, Philip; OJO, Olatunji. The diaspora of Africans liberated from slave ships in the nineteenthcentury.Journal ofAfrican History, vol. 55 , no. 3, 2014, pp. 347-369.

8

ANDERSON, Richard; BORUCKI, Alex; DOMINGUES DA SILVA, Daniel; ELTIS, David; LACHANCE, Paul;MISEVICH,Philip;OJO, Olatunji. Using african names to identify the origins of captives in the transatlantic slave trade: crowdsourcing and the registers of liberated africans, 1808-1862. History in Africa, vol. 40, no. 1, 2013, pp. 165-191; NWOKEJI, G. Ugo; ELTIS, David. Characteristics of captives leaving the Cameroons for the Americas, 1822-37. Journal of African History, vol. 43, no. 2, 2002, pp. 191-210; ELTIS, David. The diaspora of yoruba speakers, 1650-1865: dimensions and implications. In FALOLAToyin; CHILDS, MattD. (orgs.). Theyoruba diaspora in the Atlantic world. Bloomington: Indiana University Press, 2004, pp. 17-39.

9

ELTIS, David; MISEVICH, Philip (orgs.). African origins. Portal to africans liberated from transatlantic slave vessels. 2009. Available in $<$ www.african-origins.org >.Accessed 30 January 2012. started a campaign to suppress the entire transatlantic traffic. To achieve this goal, they signed treaties with several nations to prohibit the trade, deployed an anti-slave trade squadron to patrol the coasts of Africa and the Americas, and established courts for the adjudication of ships carrying slaves in violation of these treaties on both sides of the Atlantic. Whenever these ships were condemned, the court officials would freed all recaptives, meaning all Africans who had been captured in the continent and subsequently recaptured at sea by the anti-slave trade squadron, and then registertheirnamesalong with other personal details in hugeledgers. ${ }^{7}$ The lists of liberated Africans from Cuba and Sierra Leone are special in that they provide the recaptives' names in their own language, using Spanish or English script. Once these names are pronounced, individuals familiar with African languages can immediately identify to which language they belong. ${ }^{8}$ All lists of liberated Africans from Cuba and Sierra Leone are now available online in the African Origins Portal, http://www.african-origins. org. ${ }^{9}$ The following analysis of these names indicate that Africans coming from beyond the Kwango made up a minority of the total transported from Angola in the nineteenth century and they belonged to some 21 linguistic groups spread over a huge area around the upper Congo Basin.

\section{The African Origins Portal}

The African Origins Portal is an innovative instrument to trace the inland origins of slaves leaving Angola as well as any other African region in the nineteenth century. As previously mentioned, the portal provides users with access to a database of Africans rescued from slave ships by anti-slavetrade, mainly British, vesselsand disembarkedin Cubaand Sierra Leone between 1808 and 1862. The database has 6,562 records of Africans with known port of embarkation in Angola for the years 1811, 1824, 1827, $1832,1834-37,1839,1843-45$, and 1847-48; 2,315 of them disembarked in Cuba and 4,247 in Sierra Leone. These records include a wealth of information about the individuals listed, such as theirnames, approximate age, sex, height, physical description and, in a few cases, country or nation of origin, which usually consists of generic ethnic terms or places unfortunately not always identifiable on a map, such as Angola, Benguela, or Congo.

The names, however, provide reliable information to trace the origins of slaves leaving Angola. They were singular as opposed to first and second names, such as "Chando,"'Luembe," and "Mayala" in Kanyok. These names were recorded in the Africans'native tongue using English or Spanish clerks. If voiced in either of these two languages, Africans can usually recognize to which language they belong, much in the same way Europeans recognize that John, Jean, Juan, and João are respectively English, French, Spanish, and Portuguese names, even though they are just linguistic variants of the same name. Since historians know the approximate location of these languages in the nineteenth-century map of Africa, the personal names of Africans available in the African Origins Portal provide us, thus, with important clues to map the linguistic origins of slaves leaving Angola.

In order to identify the names of Africans who came from beyond the Kwango River, we decided to join forces, one of us being a historian of the slave trade, another a native speaker of Kanyok who is also fluent 
10

See for example CURTIN, Philip D. The Atlantic slave trade. A census. Madison: University of Wisconsin Press, 1969, p. 262; DOMINGUES DA SILVA, Daniel B. The Atlantic slave trade from Angola. A port-by-port estimate of slaves embarked, 1701-1867. International Journal of African Historical Studies, vol. 46, no. 1, 2013, pp. 112-113;FERREIRA, Roquinaldo.TheSuppression of the slave trade and slave departures from Angola, 1830s-1860s. História Unisinos, vol. 15, no. 1,2011 , p. 5 .

11

AnoverviewofthesegoodsisavailableatMILLER, Joseph C. Imports at Luanda, Angola: 1785-1823. In: LIESEGANG, Gerhard; PASCH; Helma; JONES, Adam. Figuring african trade. Proceedings of the symposium on the quantification and structure of theimportand exportand long-distancetrade of Africa in the nineteenth century, c.1800-1913 (St. Augustin, 3-6 January 1983). Berlin: Dietrich Reimer Verlag, 1986, pp. 162-244. in many languages spoken in Central Africa. The former is a researcher of Voyages: The Trans-Atlantic Slave Trade Database as well as the African Origins Portal. The latter is an elder man who has lived in different places of the region for most of his life and is a specialist in linguistics, philosophy, and theology. He is also author of the only translation bearing the Vatican seal of approval of the Old and New Testaments from Greek, Hebrew, and Latin into Kanyok. Together, we identified the names of 2,464 liberatedAfricansembarkedfromAngolawithknown portofembarkation. Some 1,520 had names belonging tolinguisticgroupssituated beyond the Kwango River, such as Kanyok, Kiluba, Ruund, and Tshiluba.

Although they represented a minority of the slaves embarked, the recaptives' names clearly indicate that the slave trade extended far into the interior of Angola. Historians are thus right in asserting that the trade spread deep into the heart of Africa, but did the majority of them come from those regions? What was the proportion of one group pulled into the traffic in relation to another? Without answering these questions we will never be able to assess the impact of the trade on Africa. The names by themselves are not sufficient to estimate the overall number of Africans transported from beyond the Kwango, neither the relative proportion of one linguistic group forced into the trade to another. Their distribution reflects the British efforts to suppress the traffic and not the actual movement of the transatlantic slave trade. Therefore, they need to be calibrated to avoid the bias in the sources. An effective way of addressing this issue is by combining the names data with estimates of the total number of slaves who left from the same ports of embarkation as the recaptives in that period. We thus used the names identified in the lists of liberated Africans to reconstruct the approximate size and proportion of the total number of Africans sold across the Atlantic from beyond the Kwango.

First, we created a variable in the database that would record the strength of our linguistic contribution. Individuals whose names we considered as belonging to a single language were associated with that particular language only. Individuals whose names belonged to two or three languages, were equally associated with those two or three languages. In other words, they were divided according to the number of linguistic contributions. This allowed us to preserve the integrity of the data available while embracing, at the same time, all the linguistic diversity that the names could offer.

Second, we divided all the records according to three regions of embarkation: Luanda and the ports north and south of Luanda. Historians have noted that the slave trade from Angola varied according to the ports ofembarkation.Some of these ports may haveserved the sametraderoute from the interior, but others drew slaves from different regional sources. ${ }^{10}$ The northern ports, for example, drew most of their slaves from within the basin of the Congo River; the southern ports, from the central plateau; while Luanda, which served as a major hub for the transatlantic trade, received slaves from all regions in the interior of Angola. Traders based on each of these ports organized caravans to take goods into the interior and exchange them for slaves. These goods included a variety of commodities, such as textiles, alcoholic beverages, firearms, gunpowder, and a number of other items. ${ }^{11}$ To avoid costs associated with transportation, traders sought the closest slavemarkets to their homeport.This also allowed them to reduce losses with slave mortality during the return trip. Portuguese as 
13 DOMINGUES DA SILVA, Daniel B. Op. Cit., pp. 121-122. well as African authorities benefitted from this arrangement, because it enabled them to tax traders travelling between the ports and the inland markets. Although traders sometime tried to evade taxation by marching underground, theyoften preferred theusual,saferroutescontrolled byPortugueseand Africanauthorities. ${ }^{12}$ Consequently, each portdevelopedlinks with specific regions inland and the more powerful a port grew, the more it spread its tentacles into the interior.

Finally, we multiplied the linguistic ratio of recaptives who left from each of these three regions by the estimated number of slaves embarked from thesameregionsavailableinaseparatestudy. ${ }^{13}$ Thisoperation is important because some ports exported more slaves than others. For example, Luanda was the principal port of slave embarkation in Angola. As a consequence, five percent of, say, Tshiluba slaves leaving Luanda are considerably more than five percent of Tshiluba slaves leaving from any otherport.Next,wecomputed theestimatednumberofAfricansembarked fromthesethreeregionsbylinguisticgroupand distributed theaggregated totals over a map. The final results are located in Appendix A and represented below in Figure 1.

Fiaure 1 - Slaves Shinned from Bevond the Kwanao bv I inauistic Grouns. 1811-1848

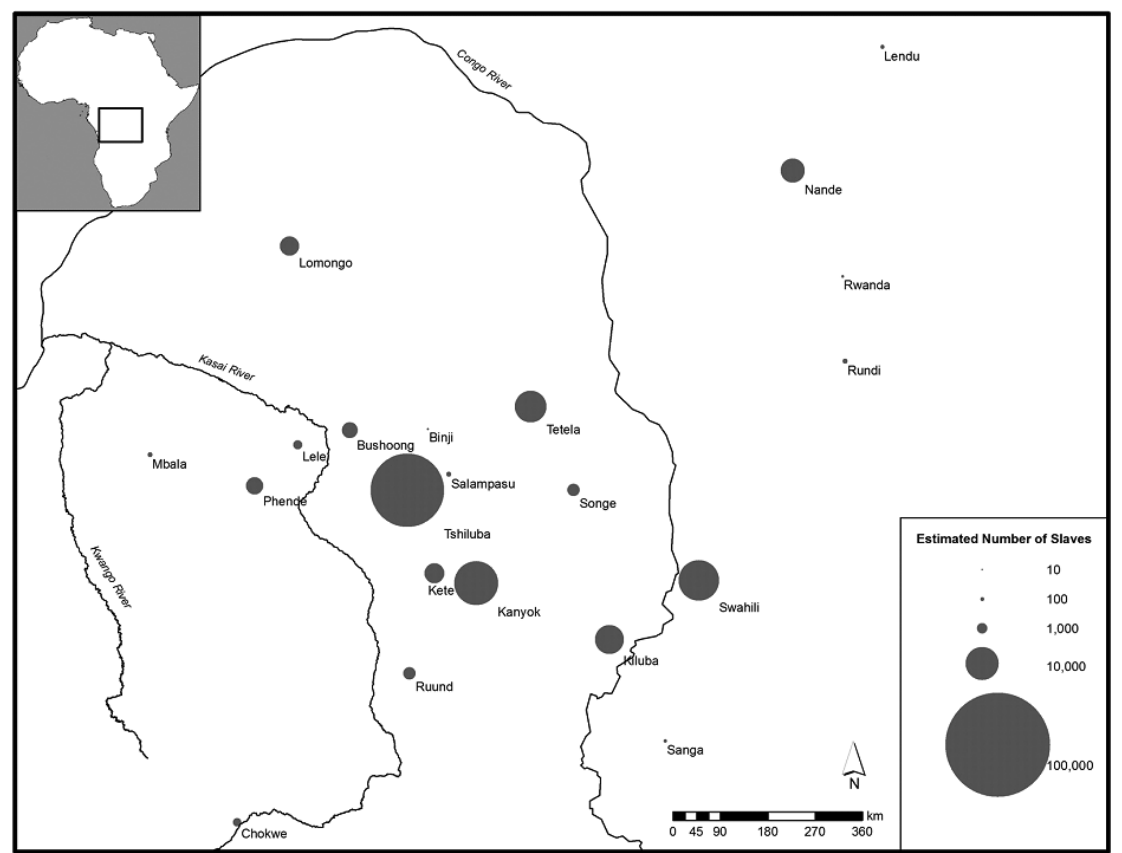

Source: Appendix A.

From Beyond the Kwango

Africanscoming from beyond the Kwangocomprisedabout 121,600 slaves, or 21 percent of the total estimated number of slaves leaving Angola between 1811 and 1848. They belonged to some 21 linguistic groups, with the majority coming from the Luba linguistic family. This estimate is still generous. Although we identified names associated with linguistic groups located in this region for approximately 23 percent of the individuals recorded, the sample used to trace the linguistic origins of Africans from the region beyond the Kwango comprises no more than 3 percent of the estimates. However, as demonstrated below, the results corroborate 
14

REEFE, Thomas $\mathrm{Q}$. The rainbow and the kings. A history of the Luba Empire to 1891. Berkeley: University of California Press, 1981, pp. 130-132.

15

Ibidem, p. 133-136.

16

Ibidem, pp. 132-133 and 138-140.
17

YODER, John C. The kanyok of Zaire. An institutional and ideological history to 1895. Cambridge: Cambridge University Press, 1992, pp. 69-74.

18

Ibidem, pp. 70-71.

19

Ibidem, pp. 74-77.

20

NURSE, Derek; SPEAR, Thomas T. The swahili. Reconstructing the history and language of an african society, 800-1500. Philadelphia: University of Pennsylvania Press, 1985, pp. 6-10; PERSON, Michael N. Port cities and intruders. The swahili coast, India, and Portugal in the early modernera. Baltimore: Johns Hopkins University Press, 1998, pp. 63-64. much of the historians' view about the major events taking place in the region during the 1830s and 1840s, the main period covered by lists of liberatedAfricans.Theyalsochallengeconventionalideasaboutthespread of Swahili in Central Africa and the role of the Lunda Empire in the transatlantic slave trade.

In the 1830s and 1840s, the expansion of the Luba Empire, under the reign of King Kumwimbe Ngombe (ca.1810-ca.1840), dominated the history of Central Africa. The expansion unfolded on three fronts but it did not succeed in all three. The northern campaigns from the Luba heartland, associated in Figure 1 with the location of the Kiluba speakers, resulted in the conquest of the eastern Songe speaking people and the foundation of Buki's Fire Kingdom, a client state governed by a Luba general. ${ }^{14}$ The eastern campaigns were not as successful. The king was able to secure the loyalty of the Kikondja Kingdom, in the Upemba depression, but met with resistance from the Bwile, Hemba, Tabwa and Tumbwe chiefdoms, located east of the Congo River. ${ }^{15}$ In the southern front, the Luba forces met with a formidable opponent, the Kazembe, who defeated the king's army in the Luapula Battle and put an end to the Luba expansion in the region. ${ }^{16}$ King Kumwimbe Ngombe's military activities in this period were no doubt responsible for the enslavement and sale of many Kiluba, Sanga, Songe, Tetela, and Tshiluba speakers into the transatlantic slave trade. The Kiluba and Tshiluba alone, members of the Luba linguistic group, made up approximately 47 percent of the total estimated number of slaves coming from beyond the Kwango.

Kanyok centralization and state formation also shaped the slave tradefrombeyondtheKwango.Inthebeginning ofthenineteenthcentury, Kanyok leaders grew resentful of the Luba presence in their territory and the humiliation with which Luba kings treated them when they visited the Luba court. The Kanyok had long been a client state of the Luba Empire, but they decided to break free from Luba domination by driving them out of their territory, raising an army, and protecting their homeland from future Luba attacks. ${ }^{17}$ This was a violent process and, as indicated by the large fortifications built at this time around Mulundu, the Kanyok capital, may have resulted in many prisoners of war sold into the trade. ${ }^{18}$ Figure 1 shows that Kanyok and Tshiluba speakers made up the majority of the slaves coming from beyond the Kwango.TheKanyokcontinued to consolidate the central power until the mid-nineteenth century by normalizing commercial and diplomatic relations with the Lunda Empire - their more powerful southwestern neighbor - taxing the slave trade from the Kanyok Kingdom, conquering the saltmarshes ofBeneMatamba, and resistingadditional Luba attacks. ${ }^{19}$ Kanyok speakers sold into the trade made up about 14 percent of the total estimated number of slaves carried from beyond the Kwango.

Although the estimates support much of the scholars'view about the regions'main historical events, theyalsochallenge conventionalideas. One of these ideas refers to the spread of Swahili in Central Africa, a language spoken originally on the coast of present day Kenya and Tanzania. Although some historians trace the presence of Swahili in the continent's interior to earlier times, is it often assumed that it spread as an important language in the region during the late nineteenth century, following the arrival of Tippu Tip, a major ivory and slave trader from Zanzibar. ${ }^{20}$ The names available in the lists of liberated Africans, however, suggest that 
21

MILLER, Joseph C. Op. Cit., 146-147; OPPEN, Achimvon.Op.Cit., p.61;THORNTON, JohnK.,Op. Cit., p., 7; VANSINA, Jan. Op. Cit., p. 403.

22

LEITÃO, Manoel Correia; SEBESTYEN, Eva; VANSINA, Jan. Angola's eastern hinterland in the 1750s. A text edition and translation of Manoel Correia Leitão's 'Voyage' (1755-1756). History in Africa, vol. 26, 1999, p. 347

23

For the extension of the Lunda empire in the nineteenth century see THORNTON, John K. Op. Cit., 1.

24

D. António Saldanha da Gama to Viscount of Anadia, 18 January 1808, Arquivo Histórico Ultramarino, Angola, box 119, document 2.

25

There are two versions of these slaves' account. TheyareavailableinBAPTISTA,PedroJoão.Viagem deAngolaparaRiosdeSenna.AnnaesMarítimose Coloniaes, vol. 3, no. 5, pp. 162-190; vol. 3, no. 6, pp. 223-240; vol. 3, no. 7, pp. 278-297; vol. 3, no. 9, pp. 423-440; vol. 3, no. 10, pp. 493-506; vol. 3, no. 11, pp. 538-52, 1843.

26

REEFE, Thomas. Op. Cit., pp. 120-121.

27

Ibidem, pp. 138-144.
Swahilimay havespread somewhatearlier.Theyincludeseveraltraditional Swahilinames immediately identifiable in the documents, such as Pemba, Samba, and Simba. These individuals may have been captured in raids or assaults to trading caravans in the easternmost regions of Central Africa and carried across the continent for sale on the western coast through the same routes that Africans used to trade salt, copper, and iron within the continent. Swahili names were the third largest linguistic group identified in the lists, making up about 12 percent of the total estimated number of slaves carried from beyond the Kwango.

Another idea that the estimates challenge refers to the role of the Lunda Empire in the transatlantic slave trade. As previously mentioned, several historians considered the Lunda, associated here with the Ruund speakers, as the principal suppliers of slaves leaving Angola. ${ }^{21}$ In the eighteenth century, the Lunda Empire expanded rapidly throughout the interior thanks in large part to their military might. A Portuguese trader who traveled to the Kwango valley in the mid-eighteenth century noted that the Lunda ruler was"very powerful, and from his realms and domains captains come forth who are sent forth by him to the West, the North, and the South, and other parts with troops of very many people to capture slaves which they sell, according to the place closest to where they take them..." ${ }^{22} \mathrm{HistoriansgenerallybelievethattheLundaexpansioncontinued}$ into the nineteenth century, with the empire reaching its largest extent under King Naweji II (died 1852), but the lists of liberated Africans contain a small number of Ruund names - in fact, one of the smallest identified suggesting that the Lunda expansion may have peaked earlier and that by the 1830 s and 1840 s it had already been completed. ${ }^{23}$

Other evidence supports this contention. Despite being considered one of the most powerful empires in Central Africa, the Lunda never crossed the Kwango. Other African polities always dominated the access to the coast. The empire's external trade was also insignificant. In 1807, a Lunda embassy reached the coast but failed to open direct commercial relations with the Portuguese. ${ }^{24}$ Between 1804 and 1808 , a couple of slaves living under Portuguese rule in Angola traveled across the continent and reported a lively trade in salt within the empire, but not a significant external trade in this commodity, much less in slaves..$^{25}$ Years later, in the $1850 \mathrm{~s}$ and 1870s, European travelers crossing the region observed an almost complete drought in commercial relations between the two most powerful polities in Central Africa. As Thomas Reefe noted, "if we are to believe Livingstone and Cameron, neither the Luba nor the Lunda kings wished to establish contact with one another during the nineteenth century." ${ }^{\prime 26} \mathrm{Fi}-$ nally, Lunda military power at this time seemed to be in decline. Although, theylaunchedseveralcampaignsalongtheempire'ssouthwesternborders, near the Angolan highlands, other regions remained unattended, allowing important client states to break free from Lunda domination. The most relevant case was the Kingdom of Kazembe, located in the Luapula valley, not too far from the Portuguese settlement of Tete in Mozambique, which by 1832 was not only governed by a royal dynasty, as it was also free from both Lunda and Luba domination. ${ }^{27}$ The estimates, therefore, fit well in this context of political decline or stagnation. Ruund speakers did not figure prominently in the nineteenth century slave trade, neither as perpetrators nor as victims, making less than 2 percent of the slaves coming from beyond the Kwango. 


\section{Conclusion}

The estimates generated from the African Origins Portal show that slaves coming from beyond the Kwango comprised a minority of the overall number of captives leaving Angola in the nineteenth century. They belonged to some 21 linguistic groups, with the majority coming from the Luba linguistic family. Although the estimates were based on a small sample of recaptives, they support much of the historians'views about the major events taking place in Central Africa during the 1830s and 1840s, such as the Luba expansion and the formation of the KanyokKingdom. But they also question previous assertions about the spread of Swahili in the continent's interior and the role of the Lunda Empire in the transatlantic slave trade.

The names available in the lists of liberated Africans provide us with an alternate way of tracing the origins of slaves carried across the Atlantic and understanding its impact on regions as remote as the Kwango River. Some of these regions lack any form of written records until the late nineteenth century, and oral traditions and archeological findings have so far provided little information on the history of the slave trade in these regions. The recaptives'names, therefore, when combined with estimates of slaves shipped and compared with other sorts of evidence, provideus with important clues and innovative ways for tracing the origins of thousands ofenslaved peoplesoldoverseasand determiningimpactoftheslavetrade on distant African regions.

The African Origins Portal has compiled all presently known lists of liberated Africans from Cuba and Sierra Leone and organized the recaptives'names online in a comprehensive and easy to use database. The task of charting the starting point of this huge migration, however, is far from complete. The slave trade involved people from very diverse ethnic and linguistic backgrounds. As a consequence, it requires the help of a large number of people with knowledge of African cultures and languages. The means for reaching out to these people has been made available only recently, with the technological developments in computer sciences and the Internet. The final results will depend on the public's contributions, so please give it a try and help us reconstruct the history of the transatlantic slave trade.

\section{Acknowledgements}

We would like to thank Mrs. Suzan Eltis for reviewing our paper's English.Allinterpretationsand conclusionsreachedhereare, ofcourse, our responsibility. 
Appendix A-Estimated Number of Slaves Shipped from Beyond the Kwango by Linguistic Groups, 1811-1848

\begin{tabular}{|c|c|c|c|}
\hline Linguistic groups & $\begin{array}{l}\text { Africans } \\
\text { recorded }\end{array}$ & $\begin{array}{l}\text { Estimated } \\
\text { number }\end{array}$ & $\begin{array}{c}\text { Percentage of } \\
\text { estimates }\end{array}$ \\
\hline Binji & 1 & 43 & 0.0 \\
\hline Bushoong & 36 & 2,319 & 1.9 \\
\hline Chokwe & 8 & 625 & 0.5 \\
\hline Kanyok & 164 & 17,497 & 14.4 \\
\hline Kete & 51 & 3,591 & 3.0 \\
\hline Kiluba & 87 & 7,451 & 6.1 \\
\hline Lele & 6 & 758 & 0.6 \\
\hline Lendu & 3 & 128 & 0.1 \\
\hline Lomongo & 48 & 3,431 & 2.8 \\
\hline Mbala & 4 & 170 & 0.1 \\
\hline Nande & 99 & 5,220 & 4.3 \\
\hline Phende & 31 & 2,630 & 2.2 \\
\hline Rundi & 5 & 192 & 0.2 \\
\hline Ruund & 11 & 1,440 & 1.2 \\
\hline Rwanda & 2 & 64 & 0.1 \\
\hline Salampasu & 5 & 213 & 0.2 \\
\hline Sanga & 2 & 85 & 0.1 \\
\hline Songe & 18 & 1,400 & 1.2 \\
\hline Swahili & 189 & 15,076 & 12.4 \\
\hline Tetela & 113 & 9,252 & 7.6 \\
\hline Tshiluba & 626 & 50,042 & 41.1 \\
\hline Total & 1,506 & 121,624 & 100.0 \\
\hline
\end{tabular}

Source: ELTIS, David; MISEVICH, Philip (orgs.). African origins. Portal to africans liberated fromtransatlanticslavevessels.2009. Availablein <www.african-origins.org $>$. Accessed 30 January 2012.

Bibliography

ANDERSON, Richard; BORUCKI, Alex; DOMINGUES DA SILVA, Daniel B.; ELTIS, David; LACHANCE, Paul;MISEVICH, Philip;OJO, Olatunji.Using african names to identify the origins of captives in the transatlantic slave trade: crowd-sourcing and the registers of liberated africans, 1808-1862. History in Africa, vol. 40, no. 1, 2013, pp. 165-191.

BAPTISTA, Pedro João. Viagem de Angola para Rios de Senna. Annaes Marítimos e Coloniaes, vol. 3, no. 5, pp. 162-190; vol. 3, no. 6, pp. 223-240; vol. 3, no. 7, pp. 278-297; vol. 3, no. 9, pp. 423-440; vol. 3, no. 10, pp. 493-506; vol. 3, no. 11, pp. 538-52, 1843.

CURTIN, Philip D.The Atlantic slave trade. A Census. Madison:University of Wisconsin Press, 1969.

DOMINGUES DA SILVA, Daniel B. The Atlantic slave trade from Angola. A port-by-port estimate of slaves embarked, 1701-1867. International Journal of African Historical Studies, vol. 46, no. 1, 2013, pp. 107-122. 
DOMINGUES DA SILVA, Daniel B.; ELTIS, David; MISEVICH, Philip; OJO, Olatunji. The diaspora of africans liberated from slave ships in the nineteenth century.Journal of African History, vol.55, no.3, 2014,pp. 347-369.

ELTIS, David.The diaspora of yoruba speakers, 1650-1865: dimensions and implications. In FALOLA Toyin; CHILDS, Matt D. (orgs.). The yoruba diasporaintheAtlanticworld.Bloomington:IndianaUniversityPress, 2004, pp. 17-39.

ELTIS, David; BEHRENDT, Stephen; FLORENTINO, Manolo; RICHARDSON, DAVID. Voyages. The Trans-Atlantic Slave Trade Database. 2008. Available in <www.slavevoyages.org > . Accessed 30 January 2012.

ELTIS, David; MISEVICH, Philip (orgs.). African origins. Portal to africans liberated from transatlantic slave vessels. 2009. Available in <www. african-origins.org>. Accessed 30 January 2012.

FERREIRA, Roquinaldo. The suppression of the slave trade and slave departures from Angola, 1830s-1860s. História Unisinos, vol. 15, no. 1, 2011, pp. 3-13.

LEITÃO, Manoel Correia; SEBESTYEN, Eva;VANSINA, Jan. Angola's eastern hinterland in the 1750s. A text edition and translation of Manoel Correia Leitão's 'Voyage' (1755-1756). History in Africa, vol. 26, 1999, 299-364.

MILLER, Joseph C. Imports at Luanda, Angola: 1785-1823. In: LIESEGANG, Gerhard; PASCH; Helma; JONES, Adam. Figuring african trade. Proceedings of the symposium on the quantification and structure of the import and export and long-distance trade of Africa in the nineteenth century, c.1800-1913 (St. Augustin, 3-6 January 1983). Berlin: Dietrich Reimer Verlag, 1986, pp., 162-244.

- - Way of death. Merchant capitalism and the Angolan slave trade, 1730-1830. Madison: University of Wisconsin Press, 1988.

NURSE, Derek; SPEAR, Thomas T. The swahili. Reconstructing the history and language of an african society, 800-1500. Philadelphia: University of Pennsylvania Press, 1985.

NWOKEJI, G. Ugo; ELTIS, David. Characteristics of captives leaving the Cameroons for the Americas, 1822-37. Journal of African History, vol. 43, no. 2, 2002, pp. 191-210.

OPPEN, Achim von. Terms of trade and terms of trust. The history and contexts of pre-colonial market production around the upper Zambezi and Kasai. Münster: LIT Verlag, 1994.

PEARSON, Michael N. Port cities and intruders. The swahili coast, India, and Portugalintheearlymodernera.Baltimore:JohnsHopkinsUniversity Press, 1998.

REEFE, Thomas Q. The rainbow and the kings. A history of the Luba Empire to 1891. Berkeley: University of California Press, 1981.

THORNTON, John K. The chronology and causes of lunda expansion to the west, c.1700-1852. Zambia Journal of History, vol. 1, 1981, pp. 1-14.

VANSINA, Jan. It never happened. Kinguri's exodus and its consequences. History in Africa, vol. 25, 1998, pp. 387-403.

YODER, JohnC. The kanyok ofZaire. An institutional and ideological history to 1895. Cambridge: Cambridge University Press, 1992. 